\title{
Identification and functional analysis of a novel missense mutation in GJA8, p.Ala69Thr
}

\author{
Dandan $\mathrm{Li}^{1 \dagger}$, Chenjia Xu ${ }^{2 \dagger}$, Dandan Huang ${ }^{3}$, Ruru Guo ${ }^{2}$, Jian $\mathrm{Ji}^{2}$ and Wei $\mathrm{Liu}^{2^{*}}$ (D)
}

\begin{abstract}
Background: To explore the molecular genetic cause of a four-generation autosomal dominant congenital cataract family in China.

Methods: Targeted region sequencing was performed to screen for the potential mutation, and Sanger sequencing was used to confirm the mutation. The homology model was constructed to identify the protein structural change, PolyPhen-2 and Provean were used to predict the mutation impact. Functional and cellular analysis of the wild and mutant GJA8 were performed in DF-1 cells by western blotting, dye uptake assay, immunofluorescence, Annexin VFITC staining.
\end{abstract}

Results: A novel heterozygous mutation (c.205G > A; p.Ala69Thr) was identified within GJA8, which cosegregated with congenital cataract phenotype in this family. Bioinformatics analysis showed the mutation was located in a highly conserved region, and the mutation was predicted to be pathogenic. Function analysis indicated that the mutation inhibited GJA8 hemichannel activity, reduced cell tolerance to oxidative stress, changed the protein distribution pattern and inhibited the cell growth.

Conclusions: We have identified a novel missense mutation in GJA8 (c.205G > A, p.Ala69Thr) in a four-generation Chinese family and our results will further broaden the gene mutation spectrum of GJA8.

Keywords: GJA8, Congenital cataract, Hemichannel

\section{Background}

Congenital cataract is defined as a type of lens opacification that occurs at birth or at an early age, which could damage the vision development. It is estimated that the global prevalence of congenital cataract is 4.24 per 10 , 000 live births [1]. In industrialized countries, the prevalence of congenital cataract is 1 to 6 per 10,000, while in

\footnotetext{
*Correspondence: weiliu05@tmu.edu.cn

${ }^{\dagger}$ Dandan Li and Chenjia Xu contributed equally to this work.

${ }^{2}$ Tianjin Key Laboratory of Retinal Functions and Diseases, Tianjin

International Joint Research and Development Centre of Ophthalmology and

Vision Science, Eye Institute and School of Optometry, Tianjin Medical

University Eye Hospital, 251 Fukang Road, Nankai District, Tianjin 300384,

China

Full list of author information is available at the end of the article
}

China, the prevalence of congenital cataract is about 5 cases per 10,000 [2]. The incidence of congenital cataract is related to many factors, and hereditary factor is the most important one and responsible for the majority of cases [3-5]. The most common genetic pattern of congenital cataract is autosomal dominant, and there are also reports of autosomal recessive and Xlinked forms. The known mutant genes responsible for congenital cataracts include lens membrane proteins (GJA3, GJA8, MIP), crystallins (CRYAA, CRYAB, CRYBA1/A3, CRYBA4, CRYBB1, CRYBB2, CRYGC, $C R Y G D$ and CRYGS), cytoskeletal proteins (BFSP1, $B F S P 2)$, growth and transcription factors (HSF4) and others [6-11]. Among these mutant genes, the

C C The Author(s). 2020 Open Access This article is licensed under a Creative Commons Attribution 4.0 International License, which permits use, sharing, adaptation, distribution and reproduction in any medium or format, as long as you give appropriate credit to the original author(s) and the source, provide a link to the Creative Commons licence, and indicate if changes were made. The images or other third party material in this article are included in the article's Creative Commons licence, unless indicated otherwise in a credit line to the material. If material is not included in the article's Creative Commons licence and your intended use is not permitted by statutory regulation or exceeds the permitted use, you will need to obtain permission directly from the copyright holder. To view a copy of this licence, visit http://creativecommons.org/licenses/by/4.0/. The Creative Commons Public Domain Dedication waiver (http://creativecommons.org/publicdomain/zero/1.0/) applies to the data made available in this article, unless otherwise stated in a credit line to the data. 
crystalline genes and connexin genes are the most widespread, which are involved in most of reported congenital cataract cases [12].

Connexins (Cxs), clusters of membrane-spanning proteins, consist of two extracellular loops and a cytoplasmic loop that connect four transmembrane domains with the $\mathrm{NH} 2$-terminus and the $\mathrm{COOH}$ terminus in the cytoplasm [13]. Connexins compose gap junctions, which are membrane specializations that permeable to ions and small metabolites and could behave as a functional syncytium $(\leq 1 \mathrm{kDa})[14,15]$. Gap junctions mediate direct cell-cell interaction and have a great effect on the normal function and survival of cells to maintain the transparency and homeostasis of lens $[16,17]$. Six connexin subunits in the plasma membrane of two adjacent cells compose hemichannel and two hemichannels form one channel [18]. Different channels, due to the properties of the specific Cxs, play different roles including direct exchange, penetration, chemical gating and voltage-dependence gating [19-22]. These functions play a significant role in maintaining the normal metabolism of the lens.

In this work, we investigated a four-generation Chinese family affected with autosomal dominant congenital cataract. By target region sequencing, we identified a novel missense mutation in gap junction protein alpha-8 (GJA8), which substituted threonine for alanine (p.Ala69Thr), and explored the functional impact of the mutation.

\section{Methods}

\section{Patients}

This study was approved by the medical ethics committee of Tianjin Medical University Eye Hospital and was in compliance with regulations of the Declaration of Helsinki of the World Medical Association. A four-generation Chinese family was recruited and written informed consent was obtained after explanation of the nature and possible consequences of the study. The enrolled subjects were examined by the professional ophthalmologist. A 5 $\mathrm{ml}$ venous blood sample of each patient was drawn into an ethylenediamine tetraacetic acid (EDTA) sample tube.

\section{DNA sequencing and bioinformatics analysis}

Genomic DNA was extracted according to the manufacturer's standard procedure (MagPure Buffy Coat DNA Midi KF Kit, Magen, China) and the genomic DNA of the proband was sequenced on MGISEQ-2000 (PE100). The targeted sequences were captured using the BGI Exome V4 chip, which contained 527 genes related to eye diseases according to OMIM. All potential pathogenic variants were validated using conventional Sanger sequencing methods. Segregation analysis was performed in all available family members. The structures of homomeric wild-type and the mutant GJA8 were modeled by Swiss-Model Server (https://swissmodel. expasy.org) and shown using a PyMOL Molecular Graphic system, using the solved structure of connexin50 (Cx50)-protein coded by GJA8 gene as template (Protein Data Bank No.6MHY_A). Multiple sequence alignment of Cx50 sequences from different species was performed by CLUSTALW (https://www.genome.jp/ tools-bin/clustalw). In addition, the possible functional effect of the amino acid change was predicted by PolyPhen-2 (http://genetics.bwh.harvard.edu/pph2/) and Provean (http://provean.jcvi.org/index.php).

\section{Cell lines and cell culture}

Chicken embryonic fibroblast DF-1 cells obtained from the American Type Culture Collection (CRL-12203, ATCC, Maryland, USA) were used to perform functional analysis. The cells were cultured at $37^{\circ} \mathrm{C}$ in a humidified atmosphere containing $5 \% \mathrm{CO}_{2}$ in high glucose Dulbecco's Modified Eagle Medium (4.5 g D-Glucose/L, Basal Media, Shanghai, China) supplemented with 100 $\mathrm{U} / \mathrm{ml}$ penicillin, $10 \%$ fetal bovine serum and $100 \mu \mathrm{g} / \mathrm{ml}$ streptomycin (Gibco, Thermo Fisher Scientific, Inc., Waltham, MA, US).

\section{Lentiviral plasmid and gene transfection}

Lentiviral plasmids containing wild-type GJA8 and mutant GJA8Ala69Thr gene and vector plasmids were synthesized by Biogot Technology, Co. Ltd. (Nanjing, China). All constructs were verified by nucleic acid sequencing. According to the transfection protocols, the plasmids were transfected into the DF-1 cells with 20 $30 \%$ confluence $\left(5 \times 10^{5}\right.$ cells $)$ in a $60-\mathrm{mm}$ dish. The effect of gene transduction was verified by western blotting. The transfection efficiency of lentiviral plasmids in these cells was verified by western blotting.

\section{Western blotting}

Total protein was extracted using RIPA buffer (Solarbio, Beijing, China) with $20 \mathrm{mM} \mathrm{NEM}$ and 1 mM PMSF from cells. The protein concentration was analyzed by BCA assay (Thermo Scientific Inc.) and western blotting was performed by $4-15 \%$ SDSPAGE (Bio-Rad Laboratories, Hercules, CA, USA). The proteins were transferred onto polyvinylidene difluoride membranes (Bio-Rad Laboratories) after electrophoresis, and then blocked with 5\% skim milk powder and $0.1 \%$ TBS-Tween for $1 \mathrm{~h}$ at room temperature. After incubation with anti-GJA8 (ab222885; Abcam; $1: 2000)$ or anti- $\beta$-actin (ab8227; Abcam; $1: 1000)$ primary antibodies at $4^{\circ} \mathrm{C}$ overnight, the membranes were washed 5 times in $0.1 \%$ TBSTween and incubated for $1 \mathrm{~h}$ with a chicken antirabbit IgG horseradish peroxidase-conjugated 
secondary antibody (dilution, 1:2000; cat. no. sc-516, 087; Santa Cruz Biotechnology, Inc., Dallas, TX, USA) at room temperature. Super Signal protein detection kit (Pierce; Thermo Fisher Scientific, Inc.) was used to detect labeled proteins and ImageJ software (National Institutes of Health, Bethesda, MD, USA) was used to evaluate protein levels changes.

\section{Dye uptake assay}

Hemichannel activity was traced by $4 \mu \mathrm{M}$ ethidium bromide (EtBr) [23]. $1 \times 10^{5}$ DF-1 cells with GJA8 or mutant GJA8Ala69Thr or vector transgene were grown for 12 days at a low-cell density. Then cells were treated with $0.3 \mathrm{~mL} 0.5 \mathrm{mM} \mathrm{H}_{2} \mathrm{O}_{2}$ for $2 \mathrm{~h}$ and were rinsed three times with Hanks' balanced salt solution (HBSS). After that, cells were fixed with $2 \%$ PFA for $30 \mathrm{~min}$. Four fluorescence fields microphotographs were taken with a $20 \times$ dryobjective in Olympus aninverted microscope with a Rhodamine filter. ImageJ software was used to measure the average pixel density of 30 random DF-1 cells.

\section{Immunofluorescence}

$5 \times 10^{5}$ DF-1 cells containing GJA8 or mutant GJA8Ala69Thr plasmid or vector transgene were cultured for $48 \mathrm{~h}$ on glass coverslips. Then the cells were fixed with $4 \%$ paraformaldehyde (Sigma-Aldrich; Merck KGaA), permeabilized for $5 \mathrm{~min}$ in $0.5 \%$ Triton X-100, blocked for $1 \mathrm{~h}$ with $3 \%$ bovine serum albumin (Sigma-Aldrich) at room temperature. Subsequently, cells were incubated overnight at $4^{\circ} \mathrm{C}$ with anti-GJA8 (1:100, ab222885, Abcam), and further incubated for $1 \mathrm{~h}$ at room temperature with Alexa Fluor ${ }^{\circ}$ 594-conjugated goat anti-

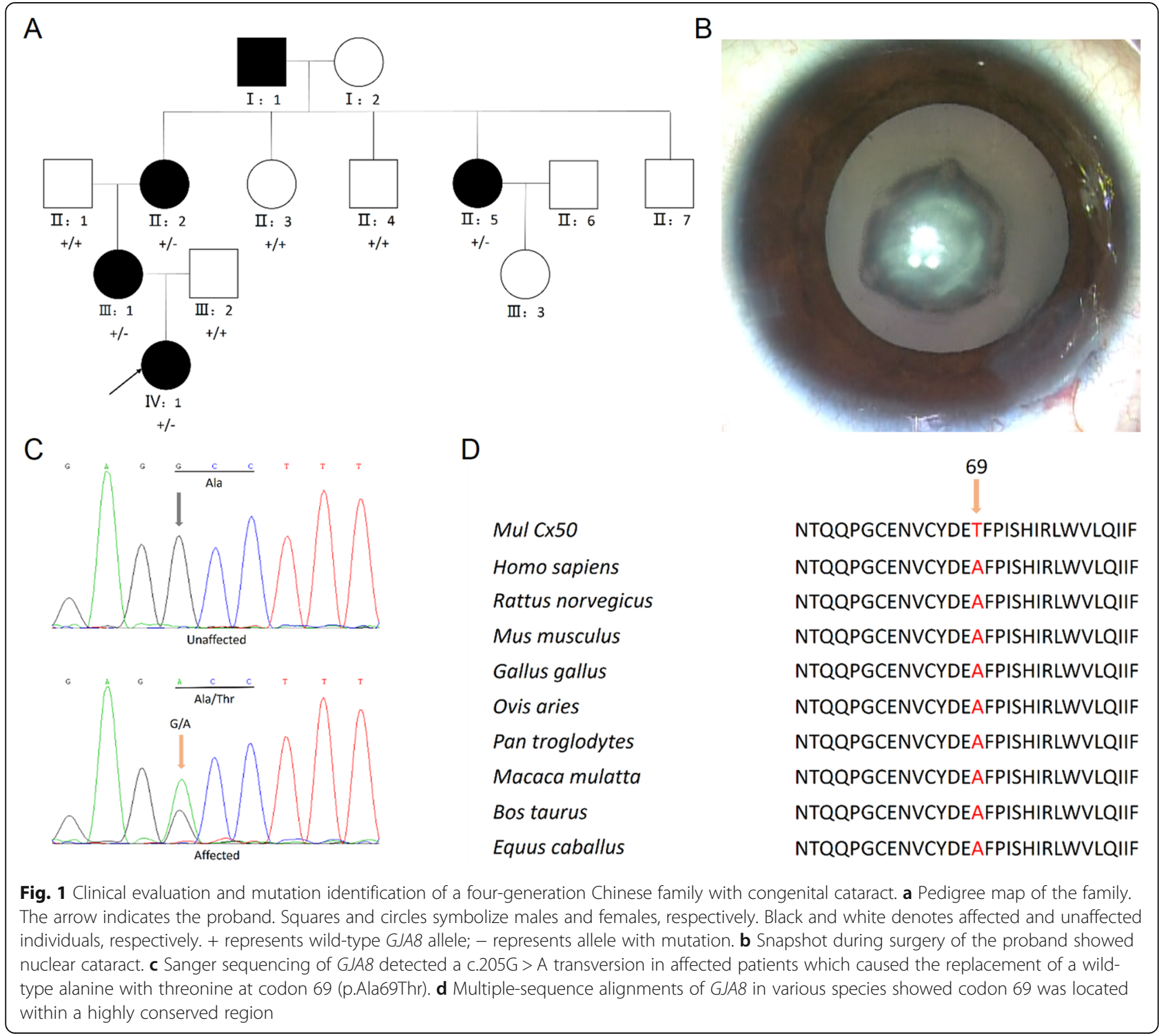


Table 1 Clinical information of enrolled individuals

\begin{tabular}{llllll}
\hline Individuals & $\begin{array}{l}\text { Age at recruitment } \\
\text { (years) }\end{array}$ & $\begin{array}{l}\text { Age at diagnosis } \\
\text { (years) }\end{array}$ & $\begin{array}{l}\text { Age at cataract surgery } \\
\text { (years) }\end{array}$ & $\begin{array}{l}\text { IOP }(\mathbf{m m H g}) \text { at recruitment } \\
(\mathbf{R}, \mathbf{L})\end{array}$ & $\begin{array}{l}\text { BCVA at recruitment } \\
(\mathbf{R}, \mathbf{L})\end{array}$ \\
\hline$\|: 2$ & 55 & 4 & 10 & $21.2,20.4$ & $20 / 40,20 / 50$ \\
$\|: 5$ & 47 & 2 & 6 & $15.6,14.3$ & $20 / 30,20 / 30$ \\
\|\|$: 1$ & 29 & 1.5 & 6 & $14.8,16.2$ & $20 / 25,20 / 20$ \\
$\| V: 1$ & 5 & 2 & 5 & $12.3,11.4$ & $20 / 200,20 / 200$ \\
$\|: 1$ & 55 & $N A$ & $N A$ & $14.6,17.8$ & $20 / 25,20 / 20$ \\
$\|: 3$ & 52 & $N A$ & $N A$ & $17.1,14.9$ & $20 / 20,20 / 25$ \\
$\|: 4$ & 49 & $N A$ & $N A$ & $19.1,15.8$ & $20 / 20,20 / 20$ \\
$\|: 2$ & 31 & $N A$ & $N A$ & $11.2,16,3$ & $20 / 20,20 / 20$ \\
\hline
\end{tabular}

IOP Intraocular pressure, BCVA Best corrected visual acuity, NA Not applicable, $R$ Right eye, $L$ Left eye

rabbit IgG (1:500, ab150080, Abcam). A confocal microscope (Carl Zeiss AG, Oberkochen, Germany) was used to observe protein expression and subcellular localization.

\section{Determination of dead cells}

DF-1 cells were exposed to $1 \mathrm{~mL} 0.5 \mathrm{mM} \mathrm{H}_{2} \mathrm{O}_{2}$ for $10 \mathrm{~h}$ when they grew to $90 \%$ confluence, and were trypsinized and collected subsequently. Using the Dead Cell Apoptosis Kit (BioLegend, San Diego, CA), Annexin VFITC staining was examined in cell suspension according to manufacturer's instructions. At least three random fields were examined under a fluorescence microscope for each condition treated.

\section{Colony formation assays}

$2 \times 10^{3}$ DF-1 cells with GJA8 or mutant GJA8Ala69Thr or vector transgene were seeded in 6-well plates. The cells were fixed with $4 \%$ paraformaldehyde for 30 mins after 14 days of culture. The colonies were stained with $5 \%$ crystal violet for 30 mins after washing with PBS again. Colonies exceeding 50 cells were counted using ImageJ. Twenty clones in each group were randomly selected, their diameters were measured, and the averages were compared by appropriate statistical methods. Each group consisted of three duplicates, and the experiment was performed three times.

\section{Statistical analysis}

The data were analyzed using GraphPad Prism 6 (GraphPad Software, Inc.). Comparisons between two groups were analyzed using Student's t-test. Differences among multiple groups was analyzed by one-way ANOVA followed by Tukey's post hoc test. $P<0.05$ was considered to indicate statistically significant differences. All experiments were repeated at least three times.

\section{Results}

\section{Clinical evaluation}

Four patients (II:2, II:5, III:1, IV: 1) and four normal individuals (II:1, II:3, II:4, III:2) from this family were enrolled in this study (Fig. 1a). The proband was a fiveyear-old girl (IV: 1) and was diagnosed with bilateral nuclear congenital cataract (Fig. 1b). On presentation, the visual acuity of both eyes was 20/200. The axial
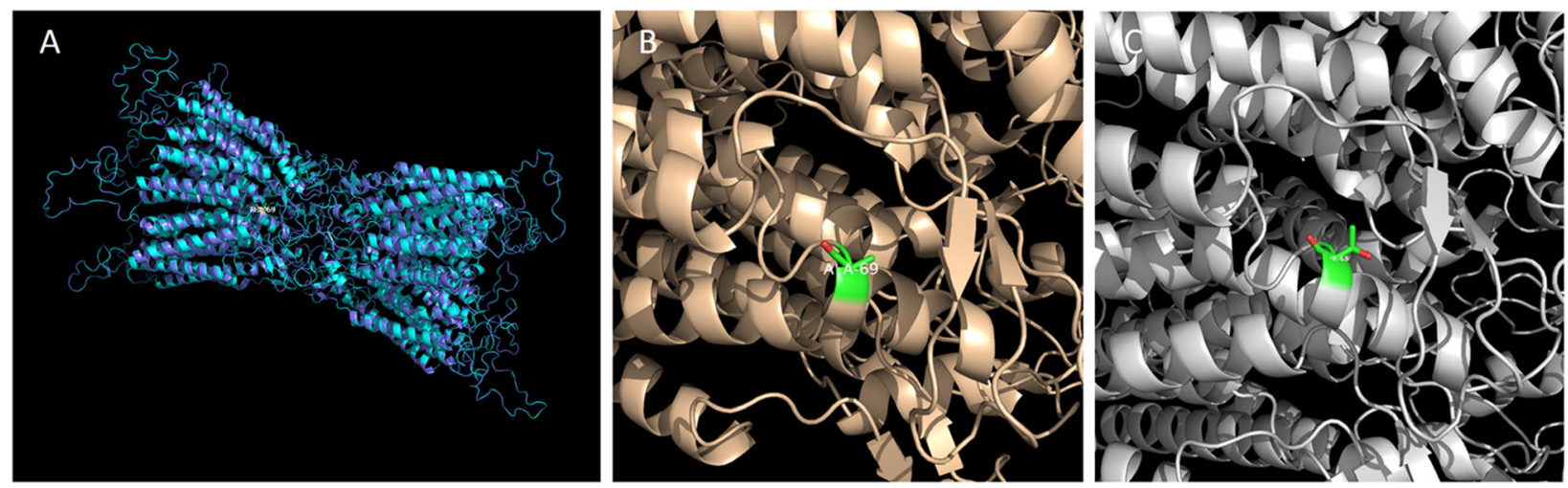

Fig. 2 Structure homology modeling of GJA8. a Side view of overlapped wild-type and p.Ala69Thr mutant GJA8 in cartoon form, showing little change on the overall structure of the protein. b Highlighted codon 69 amino acid side chain of wild-type GJA8. c Highlighted codon 69 amino acid side chain of p.Ala69Thr mutant GJA8 

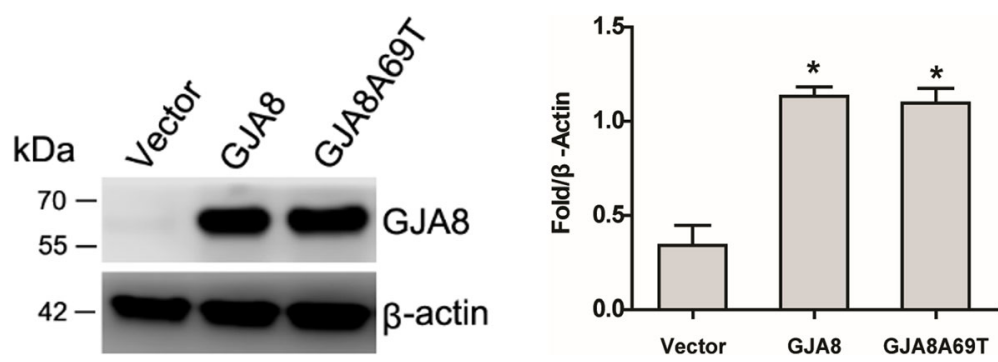

Fig. 3 Western blot verified successful transfection of DF-1 cells with wild-type GJA8 and mutant GJA8Ala69Thr gene

length was $20.06 \mathrm{~mm}$ and $20.02 \mathrm{~mm}$, the anterior chamber depth was $2.43 \mathrm{~mm}$ and $2.62 \mathrm{~mm}$, the lens thickness was $4.27 \mathrm{~mm}$ and $4.22 \mathrm{~mm}$, the flat $\mathrm{K}$ was $39.76 \mathrm{D}$ and $40.18 \mathrm{D}$, the steep $\mathrm{K}$ was $41.16 \mathrm{D}$ and 42.47 $\mathrm{D}$ for the right eye and left eye, respectively. The other 3 affected individuals were diagnosed congenital nuclear cataract and accepted cataract surgery several years ago. Other ocular or systemic abnormalities have not been found in this family. There was no consanguineous marriage in this family. The detailed clinical information of the enrolled individuals is displayed in Table 1.

\section{Mutation identification in GJA8}

Targeted exome sequencing containing 527 eye diseasesrelated genes of the proband (IV: 1 ) revealed a transversion in exon 2 (c.205G > A) of GJA8 and a frameshift deletion in exon 2 (c.37delC) of TMEM138 without any change in the remainder of the coding sequence. The mutations of TMEM138 are reported to be responsible for Joubert syndrome, which is inconsistent with the phenotype of our family. By further Sanger sequencing, the mutation (c.37delC) of TMEM138 was not found either in the unaffected family members or in other affected family members. Therefore, we do not think the mutation of TMEM138 detected in the proband is responsible for this congenital cataract family. The GJA8 mutation causes the replacement of a wild-type alanine with threonine at codon 69 (p.Ala69Thr; Fig. 1c). The mutation can be detected in all affected patients enrolled in this study (II:2, II:5, III:1, IV: 1) and was not found in the unaffected family members (II:1, II:3, II:4, III:2) by further Sanger sequencing.

\section{Bioinformatics analysis}

Multiple-sequence alignments of GJA8 in various species showed codon 69 was located within a highly conserved region (Fig. 1d). The online bioinformatics software PolyPhen-2 indicated the mutation was "probably damaging" with a score of 1.0. Provean gave a score of -2.704 , which predicted a "deleterious" effect of the mutation. The homology modeling showed no evident change on the overall structure of the protein (Fig. 2a), the amino acid conformation was not altered either except for some side chains difference of Thr and Ala (Fig. 2b, c).

\section{Functional analysis}

We got the successful gene transfection confirmed by western blot (Fig. 3, supplementary figure 1).

The EtBr dye uptake assay was used to determine the hemichannel activity change. From Fig. 4, we found no increase in dye absorption after treatment with $\mathrm{H}_{2} \mathrm{O}_{2}$ in GJA8A69T cells while the dye uptake increased after $\mathrm{H}_{2} \mathrm{O}_{2}$ treatment in GJA8 cells, indicating the hemichannel activity was inhibited by the mutation.

Confocal immunofluorescent analysis showed that the Cx50 proteins expressed by cells transfected with wildtype GJA8 were mainly present on the cell membrane and the p.Ala69Thr mutation resulted in presence of more Cx50 protein in cytoplasm (Fig. 5), indicating that
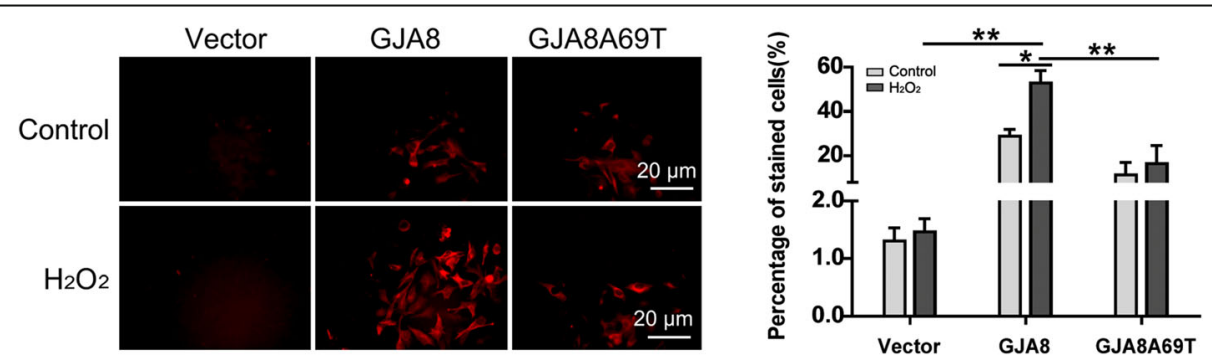

Fig. 4 Dye uptake assay. After $\mathrm{H}_{2} \mathrm{O}_{2}$ treatment, EtBr uptake was increased in GJA8- expressing cells but not in cells expressing mutant GJA8A69T (Student's t-test and ANOVA, ${ }^{*} p<0.05,{ }^{* *} p<0.01$ ) 


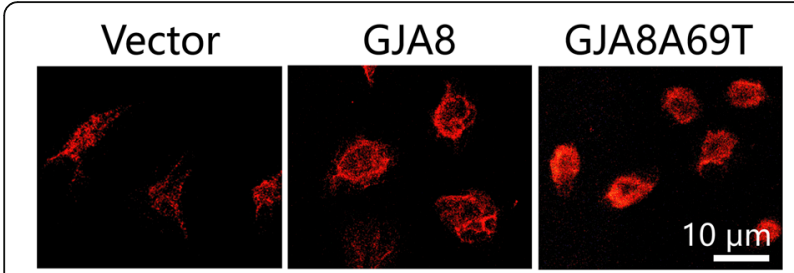

Fig. $5 \mathrm{Immunofluorescent} \mathrm{imaging} \mathrm{showed} \mathrm{more} \mathrm{protein}$ accumulation in the cytoplasm in mutant GJA8Ala69Thr cells

Cx50 p.Ala69Thr protein caused a mislocalization and translocation into cytoplasm.

The cell colony assays showed a smaller colony size of mutant p.Ala69Thr cells, compared with wild-type control (Fig. 6), indicating the mutation inhibited cell growth in vitro.

The Annexin V-FITC staining assay showed more cell death in mutant cells than wild type cells after $\mathrm{H}_{2} \mathrm{O}_{2}$ (Fig. 7), indicating the mutant cells had a reduced tolerance to oxidative stress induced by $\mathrm{H}_{2} \mathrm{O}_{2}$ treatment.

\section{Discussion}

In this study, by targeted sequencing (527 genes related to eye diseases according to OMIM were included) and Sanger sequencing, a novel heterozygous mutation (c.205G > A; p.Ala69Thr) within GJA8 was identified. Function analysis indicated that the mutation inhibited GJA8 hemichannel activity, reduced cell tolerance to oxidative stress, changed the protein distribution pattern and inhibited the cell growth.

Cx50, encoded by GJA8, has its unique characteristics. The hemichannel formed by Cx50 is monovalent cation sensitive and more sensitive to extracellular acidification [12]. Studies also indicated that the Cx50 gap junction gates have positive relative polarity and Cx50 hemichannel currents could be reversibly blocked by the histidine modifier, diethyl pyrocarbonate [24]. Recent studies have shown that Cx50 hemichannels possibly protect lens fiber cells from oxidative stress damage by transporting extracellular reductants [23]. However, the specific function and regulatory mechanism of Cx50 hemichannel in the lens is still unclear.

In our current study, we report that the p.Ala69Thr mutation, located in the first extracellular loop, is related to congenital cataract, examined by bioinformatics and functional analysis. Nearly 70 different mutations in GJA8 gene have been discovered so far (https://cat-map. wustl.edu/), and about half of the mutations are located in extracellular loops, indicating the two extracellular loops are mutational hot spots $[7,25]$. Several mutations have been identified near position 69 of $\mathrm{Cx} 50$ that are associated with congenital cataract, such as p.V64G, p.D67G, p.S73F, p.R76C, and p.V79L [26], suggesting that the A69 residue and surrounding region may play an important role in maintaining normal Cx50 function. However, the genotype-phenotype correlation for inherited cataract is still unclear, which needs further studies to confirm.

Although the homology modeling showed no evident change on the overall structure of the protein except for some side chains difference of $\mathrm{Thr}$ and Ala, the p.Ala69Thr mutation was predicted to be deleterious by both PolyPhen-2 and Provean with consistent results. Codon 69, where the mutation occurred, is also found to be located within a highly conserved region by multiple sequence alignments. Taken together, these data suggest that the p.Ala69Thr substitution is a causative disease mutation rather than a simple polymorphism.

Connexin hemichannels are normally inactive and are activated in response to certain stimuli and cell stress. In order to elucidate the effect of oxidative stress on connexin hemichannel activity, we infected chicken embryonic fibroblast cells with lentiviral plasmids containing wild-type GJA8 and mutant GJA8Ala69Thr, and treated the cells with $\mathrm{H}_{2} \mathrm{O}_{2}$. Our results showed $\mathrm{EtBr}$ dye uptake was increased in GJA8 cells after $\mathrm{H}_{2} \mathrm{O}_{2}$ treatment, indicating the hemichannels were successfully activated. However, for GJA8Ala69Thr cells, dye uptake was not increased after $\mathrm{H}_{2} \mathrm{O}_{2}$ treatment, suggesting the mutation inhibited $\mathrm{Cx} 50$ hemichannel activity, which will further attenuate extracellular reductants transportation [23]. The inhibition of hemichannels can also
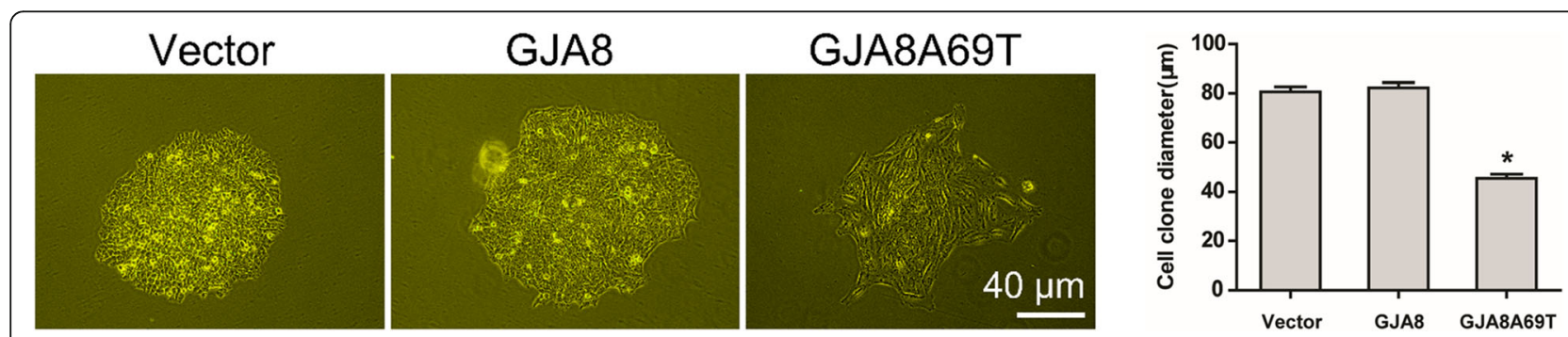

Fig. 6 Colony formation assays showed the colony size of mutated GJA8Ala69Thr group was much smaller than control groups (ANOVA, $\left.{ }^{*} p<0.05\right)$ 

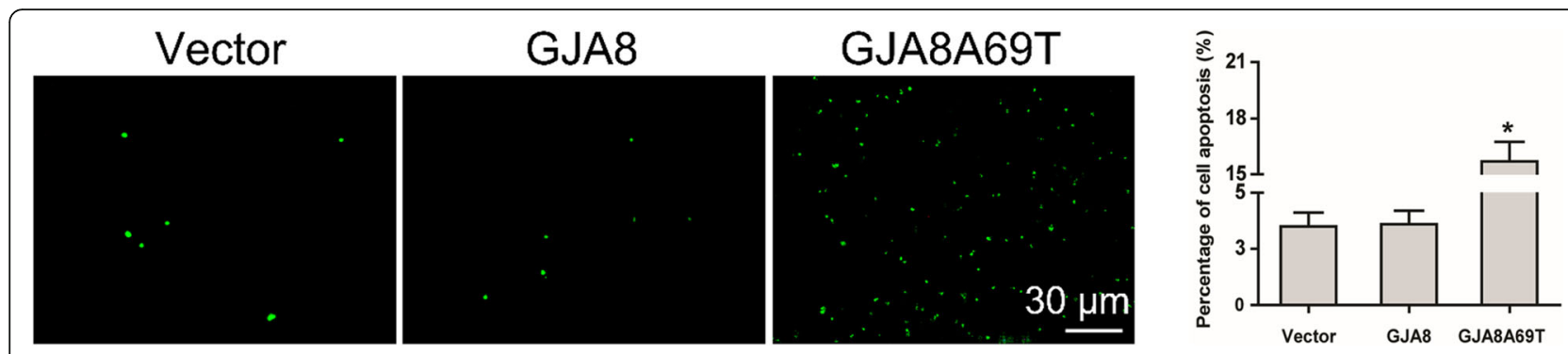

Fig. 7 Annexin V-FITC staining assay showed more cell death in DF-1 cells expressing GJA8Ala69Thr than control groups (ANOVA, * $p<0.05$ )

increase the susceptibility of the cells from oxidative stress. Our Annexin V-FITC staining assay showed more cell death in mutant cells than wild type cells after $\mathrm{H}_{2} \mathrm{O}_{2}$ treatment, indicating the mutation reduced cell tolerance to $\mathrm{H}_{2} \mathrm{O}_{2}$-induced oxidative stress, which is proved to be the major factor contributing to the development of cataract, both in vitro and in vivo [27-29].

The distribution of Cx50 protein was also affected by p.Ala69Thr mutation. Our immunofluorescent results showed that in GJA8Ala69Thr cells, more mutant protein was accumulated in the cytoplasm while $\mathrm{Cx} 50$ protein was mainly distributed in plasma membrane in GJA8 cells, indicating the mutation led to protein accumulation and caused changes in Cx50 protein localization pattern. The increased accumulation and the different distribution pattern of the mutant protein may alter the function of gap channels and unbalance the metabolism of lens fiber, eventually lead to cataract formation [25]. We found a negative effect of p.Ala69Thr mutation on cell growth, which is different from the study of Ge et al [7]. In their study, they found a positive effect of p.P88T mutation on cell growth. Although the underlying mechanism remains unclear, the distinct results highlight the high genetic heterogeneity of congenital cataract. Different mutations at the same residue render different phenotypes and different mutations lead to cataract formation by different mechanisms.

\section{Conclusions}

In conclusion, we have identified a novel missense mutation in GJA8, p.Ala69Thr, in a four-generation Chinese family with multiple individuals having autosomal dominant congenital cataract. The mutation inhibited the Cx50 hemichannel activity, reduced cell tolerance to oxidative stress, changed the protein distribution pattern and inhibited the cell growth in vitro, which may account for the underlying molecular mechanisms in this congenital cataract family. Our results can broaden the gene mutation spectrum of congenital cataract, enrich the pathogenic mechanism of congenital cataract, and may provide therapeutic target for possible gene therapy in the future.

\section{Supplementary Information}

The online version contains supplementary material available at https://doi. org/10.1186/s12886-020-01725-1.

Additional file 1 : Supplementary figure 1. The expression of GJA8 (left panel) and actin (right panel) was detected by western blot.

\section{Abbreviations}

Cxs: Connexins; GJA8: Gap junction protein alpha-8; Cx50: Connexin-50; EtBr: Ethidium bromide

Acknowledgements

We thank the family members for participating in our study.

\section{Authors' contributions}

WL and JJ designed and supervised the study; CX and DL collected the data and drafted the manuscript; $\mathrm{CX}, \mathrm{DH}$ and RG analyzed the data and helped to draft the manuscript. All authors read and approved the final manuscript.

\section{Funding}

This work was supported by a grant from The Science \& Technology Development Fund of Tianjin Education Commission for Higher Education (grant number: 2016YD09) and Tianjin Clinical Key Discipline Project (grant number: TJLCZDXKQ023). The funding sponsors were not involved in the analysis design, genotype imputation, data analysis, interpretation of the analysis results, or the preparation, review, or approval of this manuscript.

\section{Availability of data and materials}

Data used/generated by this study are available from the corresponding author upon reasonable request.

Ethics approval and consent to participate

This research followed the tenets of the Declaration of Helsinki, written informed consent was obtained from all the subjects after explanation of the nature and possible consequences of the study. For the proband (IV: 1, a five-year-old girl), written informed consent was obtained from her parents. This study was approved by the ethics committee of Tianjin Medical University Eye Hospital.

\section{Consent for publication}

Not applicable.

\section{Competing interests}

The authors declare that they have no competing interests.

\section{Author details}

'Department of Ophthalmology, Tianjin TEDA Hospital, 300457 Tianjin, China.

${ }^{2}$ Tianjin Key Laboratory of Retinal Functions and Diseases, Tianjin

International Joint Research and Development Centre of Ophthalmology and Vision Science, Eye Institute and School of Optometry, Tianjin Medical University Eye Hospital, 251 Fukang Road, Nankai District, Tianjin 300384, China. ${ }^{3}$ Department of Ophthalmology, Taihe Hospital, Hubei University of Medicine, Shiyan, Hubei, China. 
Received: 5 June 2020 Accepted: 9 November 2020

Published online: 20 November 2020

\section{References}

1. Wu X, Long E, Lin H, Liu Y. Prevalence and epidemiological characteristics of congenital cataract: a systematic review and meta-analysis. Sci Rep. 2016;6: 28564. https://doi.org/10.1038/srep28564.

2. Zhong Z, Wu Z, Han L, Chen J. Novel mutations in CRYGC are associated with congenital cataracts in Chinese families. Sci Rep. 2017;7(1):189. https:// doi.org/10.1038/s41598-017-00318-1.

3. Haargaard B, Wohlfahrt J, Fledelius HC, Rosenberg T, Melbye M. A nationwide Danish study of 1027 cases of congenital/infantile cataracts: etiological and clinical classifications. Ophthalmology. 2004;111(12):2292-8. https://doi.org/10.1016/j.ophtha.2004.06.024.

4. Lim Z, Rubab S, Chan YH, Levin AV. Pediatric cataract: the Toronto experience-etiology. Am J Ophthalmol. 2010;149(6):887-92. https://doi.org/ 10.1016/.j.ajo.2010.01.012

5. Sitorus RS, Abidin MS, Prihartono J. Causes and temporal trends of childhood blindness in Indonesia: study at schools for the blind in Java. Br J Ophthalmol. 2007;91(9):1109-13. https://doi.org/10.1136/bjo.2006.110445.

6. Li B, Liu Y, Liu Y, Guo H, Hu Z, Xia K, Jin X. Identification of a GJA3 mutation in a large family with bilateral congenital cataract. DNA Cell Biol. 2016;35(3): 135-9. https://doi.org/10.1089/dna.2015.3125.

7. Ge XL, Zhang Y, Wu Y, Lv J, Zhang W, Jin ZB, Qu J, Gu F. Identification of a novel GJA8 (CX50) point mutation causes human dominant congenital cataracts. Sci Rep. 2014;4:4121. https://doi.org/10.1038/srep04121.

8. Shentu X, Miao Q, Tang X, Yin H, Zhao Y. Identification and functional analysis of a novel MIP gene mutation associated with congenital cataract in a Chinese family. PLoS One. 2015;10(5):e126679. https://doi.org/10.1371/ journal.pone.0126679.

9. Santana A, Waiswol M, Arcieri ES, Cabral DVJ, Barbosa DMM. Mutation analysis of CRYAA, CRYGC, and CRYGD associated with autosomal dominant congenital cataract in Brazilian families. Mol Vis. 2009;15:793-800. https://doi. org/10.1016/j.visres.2008.08.017

10. Shiels A, Hejtmancik JF. Biology of inherited cataracts and opportunities for treatment. Annu Rev Vis Sci. 2019;5:123-49. https://doi.org/10.1146/annurevvision-091517-034346.

11. Shiels A, Bennett TM, Hejtmancik JF. Cat-map: putting cataract on the map. Mol Vis. 2010;16:2007-15.

12. Jiang JX. Gap junctions or hemichannel-dependent and independent roles of connexins in cataractogenesis and lens development. Curr Mol Med. 2010;10(9):851-63. https://doi.org/10.2174/156652410793937750.

13. Beyer EC, Ebihara L, Berthoud VM. Connexin mutants and cataracts. Front Pharmacol. 2013;4:43. https://doi.org/10.3389/fphar.2013.00043.

14. Hoang QV, Qian H, Ripps H. Functional analysis of hemichannels and gapjunctional channels formed by connexins 43 and 46. Mol Vis. 2010;16:134352. https://doi.org/10.1016/j.visres.2010.05.023.

15. Beyer EC, Berthoud VM. Connexin hemichannels in the lens. Front Physiol. 2014;5:20. https://doi.org/10.3389/fphys.2014.00020

16. Rae JL, Kuszak JR. The electrical coupling of epithelium and fibers in the frog lens. Exp Eye Res. 1983;36(3):317-26. https://doi.org/10.1016/00144835(83)90114-8

17. Bassnett S, Kuszak JR, Reinisch L, Brown HG, Beebe DC. Intercellular communication between epithelial and fiber cells of the eye lens. J Cell Sci. 1994;107(Pt 4):799-811. https://doi.org/10.1016/0014-4835(92)90339-T.

18. Willecke K, Eiberger J, Degen J, Eckardt D, Romualdi A, Guldenagel M, Deutsch U, Sohl G. Structural and functional diversity of connexin genes in the mouse and human genome. Biol Chem. 2002;383(5):725-37. https://doi. org/10.1515/BC.2002.076.

19. Peracchia C, Wang XG, Peracchia LL. Chemical gating of gap junction channels. Methods. 2000;20(2):188-95. https://doi.org/10.1006/meth.1999.0936.

20. Bruzzone R, White TW, Paul DL. Expression of chimeric connexins reveals new properties of the formation and gating behavior of gap junction channels. J Cell Sci. 1994;107(Pt 4):955-67. https:/doi.org/10.1083/jcb.125.2.495.

21. Harris AL. Connexin channel permeability to cytoplasmic molecules. Prog Biophys Mol Biol. 2007;94(1-2):120-43. https://doi.org/10.1016/j.pbiomolbio. 2007.03.011

22. Kjenseth A, Fykerud T, Rivedal E, Leithe E. Regulation of gap junction intercellular communication by the ubiquitin system. Cell Signal. 2010;22(9): 1267-73. https://doi.org/10.1016/j.cellsig.2010.03.005.
23. Shi W, Riquelme MA, Gu S, Jiang JX. Connexin hemichannels mediate glutathione transport and protect lens fiber cells from oxidative stress. J Cell Sci. 2018;131 (6). https://doi.org/10.1242/jcs.212506.

24. Beahm DL, Hall JE. Hemichannel and junctional properties of connexin 50 Biophys J. 2002;82(4):2016-31. https://doi.org/10.1016/500063495(02)75550-1.

25. Chen C, Sun Q, Gu M, Liu K, Sun Y, Xu X. A novel Cx50 (GJA8) p.H277Y mutation associated with autosomal dominant congenital cataract identified with targeted next-generation sequencing. Graefes Arch Clin Exp Ophthalmol. 2015;253(6):915-24. https://doi.org/10.1007/s00417-015-3019-x.

26. Rubinos C, Villone K, Mhaske PV, White TW, Srinivas M. Functional effects of Cx50 mutations associated with congenital cataracts. Am J Physiol Cell Physiol. 2014;306(3):C212-20. https://doi.org/10.1152/ajpcell.00098.2013.

27. Berthoud VM, Beyer EC. Oxidative stress, lens gap junctions, and cataracts. Antioxid Redox Signal. 2009;11(2):339-53. https://doi.org/10.1089/ars. 2008.2119.

28. Thiagarajan R, Manikandan R. Antioxidants and cataract. Free Radic Res. 2013;47(5):337-45. https://doi.org/10.3109/10715762.2013.777155.

29. Marsili S, Salganik RI, Albright CD, Freel CD, Johnsen S, Peiffer RL, Costello MJ. Cataract formation in a strain of rats selected for high oxidative stress. Exp Eye Res. 2004;79(5):595-612. https://doi.org/10.1016/j.exer.2004.06.008.

\section{Publisher's Note}

Springer Nature remains neutral with regard to jurisdictional claims in published maps and institutional affiliations.
Ready to submit your research? Choose BMC and benefit from:

- fast, convenient online submission

- thorough peer review by experienced researchers in your field

- rapid publication on acceptance

- support for research data, including large and complex data types

- gold Open Access which fosters wider collaboration and increased citations

- maximum visibility for your research: over $100 \mathrm{M}$ website views per year

At BMC, research is always in progress.

Learn more biomedcentral.com/submissions 